\title{
PENTINGNYA IKLIM ORGANISASI YANG EFEKTIF DI SEKOLAH
}

\author{
Rabukit Damanik, M. Pd \\ (Penulis adalah Ketua Prodi Adm. Pendidikan STKIP Budidaya Binjai)
}

\begin{abstract}
Abstrak
Iklim organisasi atau suasana kerja organisasi yang dilihat, dipikir, dan dirasakan oleh para pekerja diharapkan dapat menimbulkan suasana kerja yang kondusif, persuasif dan edukatif. Dalam menciptakan iklim organisasi diperlukan hubungan sosial yang harmonis antara sesama pekerja. Hubungan sosial mencakup komunikasi baik vertikal maupun horizontal, kerjasama antara para pekerja, supervisi, dukungan dari bawahan, dan kejelasan tugas yang diemban oleh masing-masing pekerja. Iklim organisasi merupakan gambaran kolektif yang bersifat umum terhadap suasana kerja organisasi yang membentuk harapan dan perasaan seluruh pegawai sehingga kinerja organisasi meningkat. Iklim sekolah yang positif merupakan suatu kondisi dimana keadaan sekolah dan lingkungannya dalam keadaan yang sangat aman, damai, menyenangkan untuk kegiatan belajar mengajar/proses pembelajaran. Iklim yang positif ini merupakan iklim sekolah yang terbebas dari kemungkinan kebisingan, keramaian mapun kejahatan. Semuanya senantiasa dalam keadaan yang tenteram, hubungan yang sangat bersahabat tampak menonjol diantara penghuninya, mulai dari kepala sekolah, guru, siswa maupun pegawai administrasi. Keadaan semacam ini menyebabkan siswa merasa aman, tenteram, bebas dari segala tekanan, ancaman yang bisa merugikan kegiatan belajarnya. Iklim sekolah yang kondusif baik fisik maupun non fisik merupakan landasan bagi penyelenggaraan pembelajaran yang efektif dan produktif. Oleh karena itu, sekolah perlu menciptakan iklim yang kondusif untuk menumbuhkembangkan semangat dan merangsang nafsu belajar peserta didik. Dengan iklim yang kondusif diharapkan tercipta suasana yang aman, nyaman, dan tertib, sehingga pembelajaran dapat berlangsung dengan tenang dan menyenangkan. Seperti halnya iklim fisik, suasana kerja yang tenang dan menyenangkan juga akan membangkitkan kinerja para tenaga kependidikan. Untuk itu, semua pihak sekolah harus mampu menciptakan hubungan kerja yang harmonis, serta menciptakan lingkungan sekolah yang aman dan menyenangkan.
\end{abstract}

Kata kunci: Iklim Organisasi Sekolah

\section{PENDAHULUAN}

Iklim organisasi bermuara kepada hubungan dalam satu situasi sebagaimana pengaruh pengalaman oleh orang-orang dalam situasi tertentu berinteraksi dengan orang lain. Dengan norma perilaku yang dilaksanakan dalam suatu organisasi, maka iklim yang baik diharapkan dapat tercipta untuk mempercepat pencapaian tujuan organisasi. 


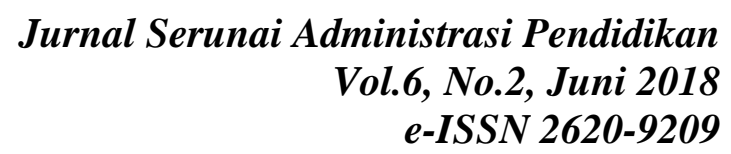

Iklim sekolah sebagai sesuatu yang dipengaruhi oleh setiap orang yang memiliki kekuatan pengaruh atas formulasi konsep atas dirinya, kemampuannya untuk bekerja efektif dan kapasitasnya untuk membangun hubungan yang memuaskan secara timbal balik dengan orang lain. Menurut Moedjiarto (2003) bahwa iklim sekolah yang positif merupakan suatu kondisi dimana keadaan sekolah dan lingkungannya dalam keadaan yang sangat aman, damai, menyenangkan untuk kegiatan belajar mengajar/proses pembelajaran. Iklim yang positif ini merupakan iklim sekolah yang terbebas dari kemungkinan kebisingan, keramaian mapun kejahatan. Semuanya senantiasa dalam keadaan yan tenteram, hubungan yang sangat bersahabat tampak menonjol diantara penghuninya, mulai dari kepala sekolah, guru, siswa maupun pegawai administrasi. Keadaan semacam ini menyebabkan siswa merasa aman, tenteram, bebas dari segala tekanan, ancaman yang bisa merugikan kegiatan belajarnya.

Dalam hal pengukuran iklim organisasi, hanya dapat dideskripsikan dan diukur secara tidak langsung melalui persepsi para anggota dalam suatu organisasi. Secara faktual, iklim organisasi selalu ada dalam setiap organisasi. Pada umumnya, iklim organisasi berakibat pada setiap pegawai dan setiap pekerjaan yang mereka lakukan, dimana setiap individu dapat pula mempengaruhi iklim organisasi. Iklim organisasi dapat dilihat dari budaya organisasi karena di dalam budaya organisasi dibicarakan halhal yang mencakup: a) perubahan organisasi, b) karakteristik organisasi, c) kreasi, d) contoh-contoh budaya organisasi dan memelihara/menjaga organisasi, e) prinsip-prinsip organisasi dan tipe-tipe organisasi. (Chaniago, 2011).

\section{KAJIAN TEORI}

\section{Pengertian Iklim Organisasi}

Iklim organisasi menurut Wirawan (2008) merupakan sekumpulan total tingkatan dan kualitas faktor-faktor lingkungan yang mempengaruhi anggota organisasi, yang biasanya diukur melalui persepsi. Iklim organisasi atau suasana kerja organisasi yang dilihat, dipikir, dan dirasakan oleh para pekerja diharapkan dapat menimbulkan suasana kerja yang kondusif, persuasif dan edukatif. Lebih lanjut, Lila (2002) mengemukakan bahwa iklim organisasi merupakan serangkaian sifat lingkungan kerja yang dinilai langsung ataupun tidak langsung oleh pegawai, yang dianggap menjadi kekuatan utama dalam mempengaruhi perilaku pegawai. Dapat dikatakan pula bahwa 


\section{Jurnal Serunai Administrasi Pendidikan \\ Vol.6, No.2, Juni 2018 \\ e-ISSN 2620-9209}

iklim organisasi merupakan gambaran kolektif yang bersifat umum terhadap suasana kerja organisasi yang membentuk harapan dan perasaan seluruh pegawai sehingga kinerja organisasi meningkat.

Iklim dapat sebagai suatu atribusi dari organisasi atau sebagai suatu atribusi dari pada persepsi individu sendiri. Iklim kerja sebuah organisasi dapat diukur melalui empat dimensi sebagai berikut:

a. Dimensi Psikologikal, yaitu meliputi variabel seperti beban kerja, kurang otonomi, kurang pemenuhan sendiri (self-fulfilment clershif), dan kuranginovasi.

b. Dimensi Struktural, yaitu meliputi variabel seperti fisik, bunyi dantingkat keserasian antara keperluan kerja dan struktur fisik.

c. Dimensi Sosial, yaitu meliputi aspek interaksi dengan klien (dari segikuantitas dan ciri-ciri permasalahannya), rekan sejawat (tingkat dukungan dankerja sama), dan penyelia-penyelia (dukungan dan imbalan).

d. Dimensi Birokratik, yaitu meliputi Undang-undang dan peraturan-peraturan konflik peranan dan kekaburan peranan. (Robbins, 1996)

Dalam menciptakan iklim organisasi diperlukan hubungan sosial yang harmonis antara sesama pekerja. Hubungan sosial mencakup komunikasi baik vertikal maupun horizontal, kerjasama antara para pekerja, supervisi, dukungan dari bawahan, dan kejelasan tugas yang diemban oleh masing-masing pekerja. Dengan kata lain, iklim organisasi merupakan nilai-nilai, kepercayaan, tradisi, dan asumsi yang diberikan kepada para pegawai, baik yang diekspresikan maupun yang tidak diekspresikan. Jadi, dapat diambil kesimpulan bahwa iklim organisasi di sekolah merupakan suatu sistem makna bersama terhadap nilai-nilai primer yang dianut bersama dan dihargai sekolah, yang berfungsi menciptakan pembedaan yang jelas antara satu sekolah dengan sekolah lainnya, menciptakan rasa identitas bagi para anggota sekolah, mempermudah timbulnya komitmen kolektif terhadap sekolah, meningkatkan kemantapan sistem sosial, serta menciptakan mekanisme pembuat makna dan kendali yang memandu membentuk sikap dan perilaku para anggota sekolah.

\section{PEMBAHASAN}

Iklim organisasi mempengaruhi praktik dan kebijakan sumber daya manusia yang diterima olehanggota organisasi. Perlu diketahui bahwa setiap organisasi akan 


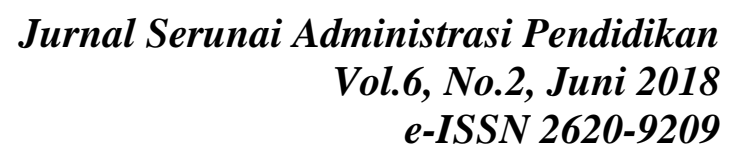

memiliki iklim organisasi yang berbeda. Keanekaragaman pekerjaan yang dirancang di dalam organisasi, atau sifat individu yang ada akan menggambarkan perbedaan tersebut. Semua organisasi tentu memiliki strategi dalam memanajemen sumber daya manusia. Iklim organisasi yang terbuka memacu pegawai untuk mengutarakan kepentingan dan ketidakpuasan tanpa adanya rasa takut akan tindakan balasan dan perhatian. Ketidakpuasan seperti itu dapat ditangani dengan cara yang positif dan bijaksana. Iklim keterbukaan, bagaimanapun juga hanya tercipta jika semua anggota memiliki tingkat keyakinan yang tinggi dan mempercayai keadilan tindakan. Iklim organisasi penting untuk diciptakan karena merupakan persepsi seseorang tentang apa yang diberikan oleh organisasi dan dijadikan dasar bagi penentuan tingkah laku anggota selanjutnya.

Berbagai kebijakan untuk mereformasi sekolah agar sekolah dapat menjadi lebih efektif yang dalam rangka meningkatkan kualitas pendidikan perlu dengan seksama memperhatikan dan memahami keunikan sekolah agar upaya perubahan dapat berhasil dengan baik. Sebagai organisasi, tentunya sekolah memiliki iklim organisasi yang berbeda-beda antara satu sekolah dengan sekolah lainnya, hal ini dikarenakan sejarah serta pembentukan budayanya masing-masing sekolah. Setiap sekolah pada dasarnya bersifat unik, dan berbeda satu dengan lainnya. Keunikan ini merupakan suatu kepribadian yang menggambarkan bagaimana sekolah tersebut melaksanakan peran dan tugasnya dalam mendidik masyarakat yang menggunakan jasa sekolah tersebut. Berkaitan dengan pengembangan keefektifan sekolah perlu didukung oleh perubahan berbagai aspek lainnya dalam pendidikan, salah satunya adalah dengan menciptakan iklim sekolah yang juga efektif. Hampir seluruh literatur keefektifan sekolah menjadikan kultur yang kuat sebagai determinasinya. Hal ini didasarkan bahwa school culture menjadi pedoman perilaku untuk mencapai tujuan.

Iklim organisasi di sekolah dapat dibina dan dikembangkan menuju kepada situasi yang kondusif dalam upaya mencapai sekolah efektif. Itu artinya, iklim organisasi di sekolah yang kurang baik dapat diubah dan dibentuk menjadi baik apabila memang pimpinan dan personil sekolah menginginkannya. Sebaliknya, jika iklim sekolah yang sudah baik bila tidak dipelihara maka akan dapat mengalami degradasi kepada kualitas yang kurang baik, sehingga sekolah mendapat penilaian yang kurag baik dari lingkungan masyarakat. Terdapat beberapa indikator iklim sekolah yang baik sebagai berikut: 
a. Tujuan-tujuan sekolah yang mencerminkan keunggulan yang ingin dicapal diperlihatkan dengan jelas kepada seluruh warga sekolah, ditetapkan dan diumumkan secara luas di sekolah.

b. Tujuan-tujuan pembelajaran akademik di sekolah dirumuskan dengan cara yang dapat diukur.

c. Fasilitas-fasilitas fisik sekolah dirawat dengan baik, termasuk segera diperbaiki fasilitas yang rusak.

d. Penampilan fisik sekolah yang bersih, rapi, dan nyaman serta memperhatikan keamanan.

e. Pekarangan dan lingkungan sekolah ditata sedemikian rupa sehingga memberi kesan asri, teduh, dan nyaman.

f. Poster-poster afirmasi (poster berisi pesan-pesan positif) digunakan dan dipajang di berbagai tempat strategis yang mudah dan selalu dilihat oleh peserta didik.

g. Sekolah menciptakan rasa memiliki sehingga guru dan peserta didik menunjukkan rasa bangga terhadap sekolahnya.

h. Kondisi kelas yang menyenangkan sehingga tercipta suasana yang mendorong peserta didik belajar.

i. Acara-acara penting di sekolah dijadwal sedemikian rupa sehingga tidak mengganggu waktu belajar.

j. Ada transisi/peralihan yang lancar dan cepat antar kegiatan-kegiatan di sekolah maupun di dalam kelas.

k. Guru mau mengubah metode-metode mengajar, bila metode yang lebih baik diperkenalkan kepadanya.

1. Penggunaan sistem moving-class.

m. Penciptaan relasi kekeluargaan dan kebersamaan.

n. Sekolah menciptakan suasana yang memberikan harapan, dimana para guru percaya bahwa peserta didik dapat mencapai tingkat prestasi yang tinggi.

o. Sekolah menekankan kepada peserta didik dan guru bahwa belajar merupakan alasan yang paling penting untuk bersekolah.

p. Harapan terhadap prestasi peserta didik yang tinggi disampaikan kepada seluruh peserta didik.

q. Harapan terhadap prestasi peserta didik yang tinggi disampaikan kepada seluruh 
orang tua peserta didik.

r. Seluruh staf dan guru berkomitmen untuk mengembangkan budaya mutu dalam menjalankan tugas sehari-hari. (Moedjiarto, 2003)

Iklim sekolah memiliki peran penting untuk menciptakan nilai dan norma sehingga sekolah yang efektif dapat tercapai. Pembentukan suasana pembelajaran yang kondusif perlu diciptakan dalam seluruh lingkungan sekolah termasuk di dalamnya lingkungan kelas. Dengan terciptanya iklim sekolah yang baik tentu akan menjadikan keefektifan sekolah akan dapat tercapai, tanpa adanya iklim sekolah yang baik tentunya sekolah yang efektif tidak akan dapat terwujud.

\section{KESIMPULAN}

Iklim organisasi penting untuk diciptakan karena merupakan persepsi seseorang tentang apa yang diberikan oleh organisasi dan dijadikan dasar bagi penentuan tingkah laku anggota selanjutnya. Iklim organisasi di sekolah dapat dibina dan dikembangkan menuju kepada situasi yang kondusif dalam upaya mencapai sekolah efektif. Itu artinya, iklim organisasi di sekolah yang kurang baik dapat diubah dan dibentuk menjadi baik apabila memang pimpinan dan personil sekolah menginginkannya. Sebaliknya, jika iklim sekolah yang sudah baik bila tidak dipelihara maka akan dapat mengalami degradasi kepada kualitas yang kurang baik, sehingga sekolah mendapat penilaian yang kurag baik dari lingkungan masyarakat.

Berbagai kebijakan untuk mereformasi sekolah agar sekolah dapat menjadi lebih efektif yang dalam rangka meningkatkan kualitas pendidikan perlu dengan seksama memperhatikan dan memahami keunikan sekolah agar upaya perubahan dapat berhasil dengan baik. Iklim organisasi di sekolah merupakan suatu sistem makna bersama terhadap nilai-nilai primer yang dianut bersama dan dihargai sekolah, yang berfungsi menciptakan pembedaan yang jelas antara satu sekolah dengan sekolah lainnya, menciptakan rasa identitas bagi para anggota sekolah, mempermudah timbulnya komitmen kolektif terhadap sekolah, meningkatkan kemantapan sistem sosial, serta menciptakan mekanisme pembuat makna dan kendali yang memandu membentuk sikap dan perilaku para anggota sekolah. 


\section{DAFTAR PUSTAKA}

Chaniago, N. S. (2011). Manajemen Organisasi. Bandung: Cita Pustaka Media Perintis.

Lila. R. (2002). Iklim Organisasi dan Budaya Perusahaan. Bandung: PT. Remaja Rosdakarya.

Moedjiarto. (2003). Manajemen Sekolah Unggul. Jakarta: Duta Graha Pustaka.

Robbins, S. (1996). Organizational Behavior (terjemahan). New Jersey: Prentice Hall.

Wirawan. (2008). Budaya dan Iklim Organsiasi: Teori Aplikasi dan Penelitian. Jakarta: Salemba Empat. 